\title{
VOCATIONS, EXPLOITATION, AND PROFESSIONS IN A MARKET ECONOMY
}

Social Theory and Practice 44.3 (July 2018) 323-347

Daniel Koltonski

Department of Philosophy

University of Delaware

Abstract: In a market economy, members of professions - or at least those for whom their profession is a vocation - are vulnerable to a distinctive kind of objectionable exploitation, namely the exploitation of their vocational commitment. That they are vulnerable in this way arises out of central features both of professions and of a market economy. And, for certain professions - the care professions - this exploitation is particularly objectionable, since, for these professions, the exploitation at issue is not only exploitation of the professional's vocational commitment but also of her even more basic commitment to morality.

\section{ADJUNCTS AND NURSES}

Universities wrongfully exploit adjunct faculty; in order to lower the cost of instruction, these institutions take advantage of their bargaining power over adjuncts to constrain pay, often to the point that full-time adjuncts live in poverty (or close to it). Or so goes the charge levied against many universities in the United States. ${ }^{1}$

At first glance, the adjunct's exploitation claim seems quite puzzling: adjuncts are normally highly educated, and so, one might think, careers in other industries - ones that pay well, or at least decently - are open to them; that they work as poorly-paid adjuncts is thus something they have chosen over these more lucrative options. On this view, even though universities might be driving

\footnotetext{
${ }^{1}$ A Google search of variations on "adjuncts exploitation" yields many articles, blog posts, and websites that detail the economic situation of adjuncts in the United States and identify adjuncts as exploited. Very little work is done, however, to explain why the current economic situation of adjuncts counts as exploitation. For instance, while Laura Finley's "How Adjuncts Are Exploited" offers an account of how adjuncts are poorly treated and compensated, it doesn't explain why their situation counts as exploitation.
} 
a hard bargain and may in fact be underpaying them, adjuncts have real exit options and so they cannot count as exploited. ${ }^{2}$ Call this the exit options response.

My aim in this paper is to show that, when it comes to the person vocationally committed to their profession, the question of exit options is a more complicated one than the exit options response supposes. Consider the adjunct who has been professionalized into academia and, as a result, her practical identity includes a vocational commitment to college teaching. For this adjunct, her vocational commitment is something that makes her vulnerable: given who she takes herself to be-and, as part of that, what she cares about-the adjunct cannot help but regard herself as having no other worthwhile choice but to accept the university's offer. In this way, even if the terms of the offer are unfair and even if there is decently-paying work available to her outside of academia, her only option, from her deliberative perspective, is to accept. This fact about her agency - refusal is not an option for her-is something the university can take advantage of and use against her by making an offer whose terms are unfair to her. Should it do so, the employment transaction between the university and the adjunct will be an exploitative one. And it will be so even while it is true of the adjunct that, were she to look for decently-paying work outside of academia, she would find it. Or so I will argue.

The broader claim is that, in a market economy, persons who are vocationally committed to their professions are vulnerable to a distinctive kind of exploitation. Because standard economic theory treats vocational commitmentsand their constitutive obligations - merely as strong preferences, the satisfaction of which via one's job counts as intrinsic compensation, it is not only unable to recognize this exploitation but at times even recommends it. $^{3}$ For instance, after

\footnotetext{
2 Jason Brennan and Phillip Magness's “Are Adjunct Faculty Exploited: Some Grounds for Skepticism" offers a version of this exit options response: they present the possibility of exit as one way that the situation of adjuncts is not relevantly analogous to that of sweatshop workers: "Adjuncts in general have good exit options. [...] The kinds of people who become adjunct faculty are highly educated and have excellent credentials. Empirical work shows that most, after they quit trying to secure permanent college faculty positions, find employment elsewhere. [...] In contrast, sweatshop workers generally don't have any other good options" (4-5).

${ }^{3}$ As Elizabeth Anderson notes in Value in Ethics and Economics, "the market does not draw any distinction between urgent needs and intense desires or between reflective desires, which can be backed by reasons, and mere tastes" (146). In economics, compensation is understood as the rewards motivating the employee's work, and so the focus is on employee motivation: intrinsic motivation - she is motivated by the meaning or fulfillment the job provides - and extrinsic motivation - she is motivated by pay. The canonical statement of the distinction is in Bruno Frey's Not Just for the Money: An Economic Theory of Personal Motivation. See also Farzin “The Effect of Non-
} 
reflecting on the thought that different kinds of compensation give an employee different kinds of motivation, the economist Anthony Heyes argues that, because "a lowly paid nurse is more likely to have a vocation, and so over perform in [her] role," a hospital ought to underpay its nurses so that, when it hires nurses, candidates motivated by their commitment to nursing (or, motivated intrinsically) are not 'crowded out' by those motivated by money (or, motivated extrinsically). ${ }^{4}$ But, if my argument is correct, Heyes' claim is really that the hospital ought to exploit its nurses' vocational commitments to nursing so that they do some work for free. And, as I will argue at the end, this exploitation is especially troubling when it comes to nursing and other care professions. ${ }^{5}$ From the nurse's perspective, it is quite difficult (if not impossible) to distinguish her vocational commitment to nursing from her commitment, simply as a person, to acting morally: her professional obligations as a nurse will also have the feel of weighty moral obligations. The result is that, when the nurse is exploited, it is not only her vocational commitment that the hospital takes unfair advantage of but also her more basic moral commitments.

Pecuniary Motivations on Labor Supply," and Besley and Ghatak, "Competition and Incentives with Motivated Agents." For general accounts of intrinsically motivated professionals hired by institutions, see Prendergrast, "Intrinsic Motivation and Incentives," and Akerloff and Kranton, "Economics and Identity." For an argument that standard economic theory cannot properly understand the role professions play in economic life, see Roberts and Dietrich, "Conceptualizing Professionalism."

${ }^{4}$ Heyes, "The Economics of Vocation," 568. It's not clear, as an empirical matter, that Heyes' suggested relationship between pay and quality bears out. For discussion of this issue, see, for instance, Nelson and Folbre, "Why a Well-Paid Nurse Is a Better Nurse"; Nelson. "Of Markets and Martyrs"; and Folbre and Nelson, "For Love or Money-Or Both?" Also, the phenomenon of 'crowding out' is much discussed. See, for instance, Frey and Jegen, "Motivation Crowding Theory"; and Benabou and Tirole, "Intrinsic and Extrinsic Motivation." The importance of this phenomenon for economic and social policy was first noted by Richard Titmuss in The Gift Relationship. There, Titmuss argues that paying for blood can be counterproductive, for the extrinsic motivation provided by the payment may cancel (or, crowd out) the intrinsic motivation provided by the donor's feelings of altruism.

${ }^{5}$ Eva Feder Kittay notes that care-workers, because of the nature of their work, are vulnerable to exploitation. But she does not elaborate on the nature of that exploitation or the precise vulnerabilities of the care workers at issue. My argument here can be seen as an attempt to spell out in more detail one way in which care-workers are vulnerable, in a market economy, to exploitation. See Kittay, Love's Labor, 64-65. 


\section{MARKET NORMS AND VOCATIONAL COMMITMENT}

Consider the following conversation. At the time, my friend Sara was an adjunct instructor at a regional university teaching a writing-intensive Introduction to Philosophy course. Our conversation concerned Sara's plans to add more writing (and thus, for her, more grading) to her course.

Me: Don't forget how little the school is paying you to teach this course. You don't get paid enough to do this additional work.

Sara: I know, I know. [pause]

$M e: \quad B u t$ you're going to do it anyway, aren't you?

Sara: Yeah, I am. My students need it.

Our conversation might seem to support the claim that adjuncts cannot be exploited: while Sara agrees that she's not getting paid for the work she's adding to the course, she admits that, from one perspective, she has the option of not adding this work - she will still fulfill her contract - and so taking it on without pay is her choice. However, Sara also thinks that, from another perspective, she does not have the option of not adding this work: she owes it to her students to assign them extra writing - they need it-and so, if she really is a college teacher and not just teaching a course for money, she must take on this extra work. And, for Sara, her sense of what matters requires that she adopt this latter perspective and so that she regard herself as having no option but to add this work.

In my discussion of adjuncts, I confine myself, somewhat artificially, to fulltime adjuncts for whom their identities as college teachers are their primary identities, the ones that largely orient their practical lives. Of course, many adjuncts are also parents, spouses, partners, siblings, activists, artists, and the like; and these identities often aren't subordinate to their identities as college teachers (and rightly so). But, since I am concerned here with how this identity as a college teacher - this vocational commitment and the obligations partly constitutive of it-makes the adjunct vulnerable to exploitation it is better for this purpose to assume a situation where the adjunct doesn't have these other identities (and the obligations partly constitutive of them) potentially competing with her identity as a college teacher when she's deciding whether to accept the university's employment offer. (The discussion of nurses later will not include this limitation.) 


\subsection{Professionals in a market economy}

Let's begin with what Elizabeth Anderson says about the place of professionals in a market economy:

Consider the status of professionals such as doctors, lawyers, academics, athletes, and artists who sell their services. Excellent performance in professional roles is judged by the standards of goods internal to the practice rather than by external instrumental criteria such as profitability. Academics pursue understanding, athletes win games, artists produce aesthetic value, and so forth. Adherence to their defining ideals and goals often involves forgoing opportunities for making money. When professionals sell their services, they enter into market relations that impose norms on their activities which potentially conflict with the norms of excellence internal to their professional roles. ${ }^{6}$

Many professionals are self-employed, selling their services directly to clients. But our concern is with professionals employed by institutions: not only are they subject to two different and incompatible sets of norms but each set governs a different interaction. On the one hand, the professional sells her services to the institution for pay; in this interaction, she is an economic actor governed by market norms. In the labor agreement, both she and the university are to be motivated by self-interest: each party "views [its] relation to the other as merely a means to the satisfaction of ends defined independent of the relationship and the other party's ends" and each party "is expected to take care of [itself]." 7 On the other hand, the professional delivers her services to clients; in these interactions, she is a practitioner of her profession, governed not by market norms but by those norms constitutive of that profession. In these interactions, then, she is not to be motivated by self-interest but rather by the aims of her profession, and so she is not to treat these interactions with clients as market transactions.

Market norms claim no limits on their application and so virtually any interaction can be approached, either partially or entirely, as a market transaction, including the professional's interactions with clients:

Lawyers may act merely as hired guns for their clients, harassing those against whom their clients have no genuine legal case. Doctors may

\footnotetext{
${ }^{6}$ Anderson, Value in Ethics and Economics, 147.

${ }^{7}$ Ibid., 145.
} 
perform profitable but medically unwarranted services on ignorant or demanding patients. ${ }^{8}$

Anderson makes particular note of this threat when it comes to for-profit firms. But even non-profit institutions such as universities and hospitals are, to varying degrees, subject to market discipline, and the demands that such discipline places on them can pose much the same threat as the demand for profit. Because the intrusion of market norms into the professional sphere is a constant threat, the professional sphere requires protection.

Of course, it's often in the institution's own long-term economic interest to protect the professional sphere. Clients will only buy the services of the institution if they think they'll get what they're paying for, which are the services of professionals. ${ }^{9}$ This point applies both to for-profit entities-advertising firms, newspapers, medical practices, etc. - and non-profit ones - universities, hospitals, social service agencies, etc. ${ }^{10}$ But, even so, institutions face the constant threat of short-term thinking urging the use of market norms within the professional sphere, since it will often be in the economic interest of some within the institution-managers, for instance, or the professionals themselves - to treat client interactions as further opportunities to make money, particularly if their own performance is judged internally by market metrics.

One way institutions protect the professional sphere from such threats is to separate it off from the rest of the institution. Advertising firms will separate the "creative" professionals from the business side; news organizations do much the same with their journalists. Of course, such separation doesn't fully eliminate the threat, as any institutional structure is porous. Indeed, this is one reason why hiring professionals with vocational commitments is also important: they will resist the inevitable pressures to treat their interactions with clients as market

8 Ibid., 148

${ }^{9}$ Admittedly, this isn't entirely correct: that clients will only buy the services if they think they'll get what they've paid for requires only that the institution convince them they're getting what they've paid for. Implicit in my argument is the assumption that most institutions cannot engage in such deceit successfully for very long, and so, over the long term, the way to convince clients that they're getting what they've paid for is, in fact, to it to give them.

${ }^{10}$ This point may not apply to lawyers, at least in an adversarial system like that in the United States, for it may very well be that what clients want are 'hired guns.' Lawyers themselves may want to practice law, but their clients may simply want them to win. For discussion of lawyer's ethics, and in particular the difficulties posed by an adversarial system, see David Luban's "The Adversary System Excuse" and "Lawyers as Upholders of Human Dignity (When They Aren't Busy Assaulting It)" in Luban, Legal Ethics and Human Dignity. 
transactions, even when doing so is in their own economic interest, as incompatible with their professional obligations.

Consider the case of the university and the adjunct. The good to be realized in the classroom is knowledge or understanding that comes about through intellectual inquiry, and thus the classroom must be a separate sphere, protected from market pressures. The university, as a seller of educations (or, at least, of credentials) has an economic interest in protecting the classroom from market pressures, for it is really only then that the course grades, and so also the resulting degree credentials, can signal students' genuine achievements to potential employers, graduate programs, etc. And the institutional design of the university offers some protection: within the classroom, the adjunct has a great deal of autonomy and, if she is supervised, it is done largely by others on the faculty; other university departments-Athletics, say, or Alumni Relations and Giving - have no official role in governing the classroom. ${ }^{11}$ That said, the adjunct's autonomy in the classroom gives her a good deal of power, and it may be economically rational for her to do minimal course preparation or to lessen her grading burden by making the course an easy A; at an extreme, she might regard her interactions with students as economic opportunities: she might, for instance, sell high grades to them. Thus, an important line of defense is the adjunct's own commitment to helping her students realize, both with her and by themselves, the good of knowledge or understanding via intellectual inquiry. If she is to resist the pressures to allow market norms to intrude into the classroom, she must think herself obligated both to pursue with her students this defining aim of the classroom and to see to it that a student's grade reflects only the extent to which they realized that good over the course of a semester. Protecting the classroom sphere thus requires hiring someone with the kind of commitment to teaching - including the commitment, as Anderson notes, to "forgo opportunities for making money," both for herself and for the university - that will motivate her to protect the integrity of the classroom. This sort of commitment, the one that Sara reveals in her conversation with me, is what I'm calling a vocational commitment. ${ }^{12}$

${ }^{11}$ Of course, these departments may sometimes still try, usually via backchannels. This is one instance of the porousness of institutional structures.

${ }_{12}$ Additionally, the adjunct professionalized as a college teacher will simply be a better teacher. What happens in the classroom during the course of a semester is unpredictable and someone with a commitment to teaching well is both more willing to and better able to navigate such situations in ways that benefit the students, individually and as a group. And, quite straightforwardly, her love 


\subsection{Vocational commitment}

So far, a vocational commitment is a kind of self-imposed constraint on action. For the adjunct, it is, roughly: when teaching a class, one must abide by the norms of the classroom, and not market norms, in one's interactions with students. That she has this commitment is partly what qualifies the adjunct to teach. However, this isn't all that a vocational commitment is, since it wouldn't really make sense for someone to have this sort of commitment unless it was also important to her that she teach, that is, unless she were also committed to teaching as an activity. These two commitments seem to come as a pair. And this is confirmed, I think, by how the process of professionalization - the years of special training required of many professions, including medicine and nursing, social work, law, academia, teaching, the fine arts - tends to work. One aim of professionalization is, of course, to impart both a thorough understanding of the practice - as an A, one aims for goods $\mathrm{p}, \mathrm{q}$, and $\mathrm{r}$ by following norms $\mathrm{x}, \mathrm{y}$, and $\mathrm{z}-$ and the particular skills and habits of mind needed to excel at the practice. But another aim is to inculcate an identity: you are an A, and, as an A, you are to aim for goods $\mathrm{p}, \mathrm{q}$, and $\mathrm{r}$ by abiding by norms $\mathrm{x}, \mathrm{y}$, and $\mathrm{z}$; failures to do so will call into question whether you really are an A. In this way, professionalization changes the person's conception of the kind of life that she thinks it worth her living. And so, when a person has a vocational commitment to her profession, she is committed both to working in that profession, and, when doing so, to living up to its demands. ${ }^{13}$

Consider what Christine Korsgaard says about identity in the sense at issue here:

[It is] a description under which you value yourself, a description under which you find your life worth living and your actions worth undertaking [...] You are a human being, a woman or a man, an adherent of a certain religion, [...] a member of a certain profession, $[\ldots]$ and so on. And all of these identities give rise to reasons and obligations. Your

for intellectual inquiry - at least when it is apparent to the students - is itself an asset in the classroom, drawing otherwise reticent, disengaged, or skeptical students into the material. ${ }^{13}$ It's been my experience, both in graduate school and beyond, that a result of professionalization into academic philosophy is the conviction, fairly common among philosophers (or at least early career philosophers), that there is nothing or, at most, very little else worth doing as a career besides philosophy. Of course, this is only anecdotal-my limited sample could be unrepresentative of the discipline-but I've been struck by how common such a conviction seems to me to be. 
reasons express your identity, your nature; your obligations spring from what that identity forbids. ${ }^{14}$

What's important here is the normativity of identity: when you come to identify as a member of a profession - when it becomes your vocation - it's not merely that you have a strong preference for that kind of work but that you have a strong preference for it because you've come to think of it as the kind of work you ought to do. The felt necessity of one's vocational obligations thus stems from the importance of maintaining one's integrity, one's sense that one is living up to the demands of one's identity, of the life that one thinks worth living. ${ }^{15}$ But so also does one's commitment to pursuing that vocation at all, for it is only if one is pursuing it that one can think of oneself as having that vocation and so as living the life that one thinks worth living. Consider my friend Sara. One of her main identities is as a college teacher; it's her vocation. This identity makes it the case both that, if offered the chance to teach, she takes herself to have powerful reasons to accept the offer, even if doing so requires sacrifice, and that, when she's engaged in teaching a course, the reasons she has for assigning work (or not) have to do with her students and what they need and not with whether she would be paid for grading that work. Her identity requires, first, that she discount as reasons for or against accepting an offer to teach what's in her economic interest and, second, that she exclude as reasons for or against conducting class in a particular way what's in her economic interest. ${ }^{16}$ It's this second requirement that's at play in my conversation with her.

The language of obligation and requirement threatens to obscure something important, however. Sara does not feel these obligations - what her vocational identity requires she do and refrain from doing in her teaching - as external impositions on her freedom of action. Rather, she endorses the identity and thus the associated obligations: they help establish the boundaries of the space of reasons in which her deliberation takes place. For Sara, conducting her course in a way that's not responsive to her sense of what her students need but rather by how much she's being paid is not merely something that she'd prefer not to do; it would be a betrayal of her vocational commitment and thus of herself, for she

\footnotetext{
${ }^{14}$ Korsgaard, The Sources of Normativity, 101.

${ }^{15}$ See Ibid., 101-03.

${ }^{16}$ The argument here is thus similar to Joseph Raz's argument in "Liberating Duties" that some duties are internally related to their justifying goods and so they are constitutive of that good (1819). The obligations of the profession are partly constitutive of that profession, and so one cannot practice that profession - it cannot be a part of one's identity - without, by in large, abiding by its constitutive obligations.
} 
would no longer be acting as a college teacher but rather someone merely teaching a course for pay. As a result, my suggestion was not an option that she merely preferred not to take but rather something she couldn't seriously entertain as an option in the first place.

\section{EXPLOITATION, COERCION, AND FORCED CHOICE}

Given that the circumstances of the employment transaction between universities and adjuncts are varied, my argument here is not that all or even many adjuncts are exploited. Rather, I aim to defend a narrower claim, namely that the exit options response to the adjunct's claim of exploitation fails for at least one important kind of adjunct - the adjunct who is vocationally committed to teaching - and it fails because the adjunct's vocational commitment can make it the case that, from her deliberative perspective, these jobs outside of academia are not genuine options for her. My argument will assume that the employment transaction between the adjunct and her university has many of the features of an everyday, morally unproblematic market exchange: the adjunct understands the terms of the offer and there is nothing impairing her decision-making; the university does not owe her the opportunity to teach and so is under no obligation to offer her a job at all; and the adjunct, and not just the university, benefits from the transaction: she is able to teach when she otherwise would not. Of course, she would have preferred a more advantageous deal, but that's common of everyday, morally unproblematic market transactions.

\subsection{Taking unfair advantage of another}

The most influential recent account of exploitation is arguably the account developed by Alan Wertheimer in Exploitation. In it, he says:

An exploitative transaction is one in which A takes unfair advantage of B. A engages in harmful exploitation when A gains by an action or transaction that is harmful to B where we define harm in relation to some appropriate baseline. A engages in mutually advantageous exploitation when, in relation to the same baseline, A gains unfairly or excessively by an action or transaction that is beneficial to B. ${ }^{17}$

${ }^{17}$ Wertheimer, Exploitation, 207. See also 208, 253. 
As Ruth Sample has pointed out, Wertheimer's account "sees exploitation as a certain kind of failure of outcome, rather than as a procedural failure." 18 An exploitative transaction, on his view, is thus simply one in which the benefits and burdens are distributed between A and B unfairly. ${ }^{19}$ And, indeed, when it comes to mutually advantageous exploitation, the main project for Wertheimer is working out how to determine whether A gains an unfair amount from the transaction with B. ${ }^{20}$ As a result, on Wertheimer's account, the thought that exploitation involves taking advantage of another does no real work and so falls away. This, I think, is a mistake, for exploitation is in part a procedural failure.

The problem for us is that Wertheimer's account is thus unable capture our dispute about whether the adjunct can count as exploited. The adjunct's claim of exploitation is not merely that she is underpaid-or, in other words, that the university gains unfairly from the transaction - but also that certain things about her give the university power over her, which it has exercised, to set the terms so that it may gain unfairly - or, in other words, that the university has taken advantage of her. And the exit options response does not dispute the adjunct's claim that she is underpaid; it disputes her claim that, in the employment transaction, the university has taken advantage of her: the fact that the adjunct has exit options means that the university lacks power over her to dictate the terms. As the exit options response has it, though she may prefer not to, the adjunct can walk away.

That it cannot capture our dispute about the adjunct points to a deeper problem with the account: an account of exploitation in which the notion of taking advantage of another does no real work has difficulty explaining why, when someone is exploited, she thereby has legitimate grounds to complain that she has been wronged by the other party to the transaction. Consider the following situation:

Truffle Oil: Marius is a shop owner. After a hurricane hits the area, he sees that he has a short window in which to make a good deal of money, and so he raises his prices, including the price of truffle oil, dramatically and to an unfairly high level. Shanice comes by the shop to buy truffle oilshe loves it but just ran out, and Marius' shop is the only one open-and, despite the price, purchases a bottle.

\footnotetext{
${ }^{18}$ Sample, Exploitation, 16.

${ }^{19}$ For Sample's argument, see Ibid., 16-26.

${ }^{20}$ Wertheimer, Exploitation, 207-46.
} 
Does Shanice have grounds to complain that she was exploited and thus wronged by the transaction? It seems to me that she doesn't, even though the transaction unfairly benefits Marius, because she could have simply refused to buy it and gone without truffle oil for a bit. She could have walked away. The obvious difference between this case and what people normally understand as price-gouging is that the latter involves something the consumer needs and so cannot be expected to be able to go without. And this difference, I think, is relevant for understanding what counts as taking advantage not merely of another person's desires or wants - what Marius does here-but of the person herself - what happens in a case of exploitation.

To see how this difference is relevant, consider more generally the charge of exploitation levelled against a proposed mutually advantageous transaction. Contained in this charge is the claim that, even though the transaction would benefit both parties, that it would be unfair to one of them gives the other an important moral reason not to propose it. This other ought not attempt to benefit unfairly. That much seems obvious. But this same fact about the transactionthat it would be unfair to one of the parties - matters also for what that party has reason to do: while the fact that the transaction would benefit her gives her reason to accept it if offered, the fact that it would be unfair to her gives her an important reason to refuse it if offered. She ought not acquiesce to him benefitting unfairly by accepting the transaction he proposes; instead, she ought to hold out for fair terms or, if that fails, walk away. In this way, the circumstances of a transaction include the responsibility of the recipient of the proposal to refuse the transaction if it would be unfair to her. ${ }^{21}$

Back to Truffle Oil. Let's suppose the purchase benefits Shanice, and it does so by satisfying one of her wants. That it would benefit her gave her a reason to purchase the truffle oil but, since the price was unfairly high, this reason to purchase it was arguably overridden by the reason she had to refuse generated by that unfairness. By buying it nonetheless, she failed to take responsibility for defending herself against unfair transactions; as a result, she can hardly complain that she has been exploited and thus wronged by the transaction. ${ }^{22}$

\footnotetext{
${ }^{21}$ Wertheimer allows that it may be prima facie wrong for the exploitee to allow herself to be exploited, and he offers several arguments for why it might be wrong. See Wertheimer, Exploitation, 293-96. My argument here is that this claim of prima facie wrongness is contained within the charge of exploitation: if the unfairness of the transaction is a reason against it, it is a reason both against proposing it and against accepting it.

${ }^{22}$ To be sure, Marius still ought to have offered a fair price, and nothing I say here requires denying that claim.
} 
Marius took unfair advantage of Shanice's wants but, because Shanice allowed him to do so instead of walking away, Marius didn't take advantage of Shanice herself and so did not exploit her. Or so an account of exploitation should claim.

For the charge of exploitation to stick, then, it must be the case that the recipient of the offer is unable to defend herself, as it were, against the unfair transaction. This will be the case, I think, either when the recipient's decisionmaking capacity is impaired in some way or when there is more at stake for the recipient than the satisfaction of some mere wants. We shall focus here on the latter possibility, since we're assuming about the adjunct that her decisionmaking capacity isn't impaired. If what's at stake is not merely some want but rather something that she cares about, the commitments partly constitutive of that care may give her important reasons to accept the unfair offer, reasons that will have the character of obligations; and these obligations may override or even silence the reason to refuse generated by the unfairness of the offer. In this sort of case, she will be unable to defend herself against the unfair transaction because refusing the offer would require betraying something she cares about.

Does this mean that, if there's more at stake for Shanice in Truffle Oil than the satisfaction of some mere want, then Marius counts as exploiting her by charging an unfairly high price? In short, yes. Suppose, for instance, that her dying mother has asked for her favorite dish one last time, a dish that requires truffle oil. Or, somewhat more fancifully, suppose that Shanice requires truffle oil for some religious ritual. In either case, Shanice will regard herself as subject to an obligation to purchase the truffle oil from Marius, one that overrides and perhaps even silences the reason she has to refuse that's generated by the unfairly high price Marius is charging. (It's likely in these cases that Marius' exploitation of Shanice will count as blameless, unless, say, the religious significance of truffle oil is common knowledge.) Now, one need not think that Shanice does in fact have the relevant obligations in either case; what matters for the question of exploitation is that she thinks she does, for it is this fact about her will - what she cares about - that Marius uses against her. ${ }^{23}$ (To emphasize, even if Shanice buys the truffle oil because, on her view, she must, the transaction is unobjectionable provided that Marius charges her a fair price. The unfairness of the terms is necessary for exploitation.)

\footnotetext{
${ }^{23}$ This isn't to deny that the question of whether she does have these obligations - and so whether she really needs truffle oil-is relevant in other ways, for a person's genuine needs may ground claims on others that her merely felt needs will not. The point here is only to say that, for the question of exploitation, whether she really needs truffle oil is irrelevant.
} 
Here then is what can make a mutually advantageous but unfair transaction a case of exploitation: the exploiter takes advantage not of some mere wants but rather of the felt obligations arising out of what the exploitee cares about, obligations that make it the case that, despite the unfairness, she cannot regard refusing the offer as a genuine option for her; and, by doing this - by using what she cares about as a vulnerability of her agency - the exploiter takes advantage of her and thus wrongs her. ${ }^{24}$

\subsection{Forcing another's choice: coercion}

On my account, one way to exploit another is to use what that person cares about as a vulnerability of her agency so that, from her own deliberative perspective, she has no option but to accept the transaction you propose even though the terms are unfair to her. Given what she cares about, refusing is not an option for her and so, in that sense, she is forced to accept. This claim about exploitation and forced choice is likely to be met with skepticism, since it conjures up images of guns to heads and the like. But, as a matter of fact, thinking about cases of coercive threats, even of guns to heads, will prove useful in getting a handle on the force at issue in the cases of exploitation that concern us. Consider a mugging:

Mugging 1: Sreena is walking down the street with her daughter Neelam when Max approaches and, brandishing a handgun, threatens to kill Neelam if Sreena doesn't hand over her wallet. Sreena decides to comply and so she gives Max her wallet.

Max's wrongful threat to kill Neelam gives Sreena no choice but to hand over her wallet; or, alternatively, the cost-Neelam's death - that Max has wrongly attached to refusal forces Sreena's choice. If there's any case of genuinely forced choice, you might think, it's Mugging 1. But why is that? Max's threat attaches a severe cost to refusal and so changes the choice calculus for Sreena: what she now has most reason to do is hand over her wallet. But why does this change force her choice to hand over her wallet? Consider a different mugging:

Mugging 2: Bashir is walking down the street carrying a small chocolate cake that he's eagerly anticipating eating once he arrives home. Greta

${ }^{24}$ On Allen Wood's account, exploiting another involves taking advantage of some vulnerability they possess, though he suspects that there is little we can do to clarify the notion of vulnerability at work here beyond admitting that needs and desires can sometimes constitute vulnerabilities. See Wood, "Exploitation," 141-145; and Wood, Karl Marx, 246-53. 
approaches, takes his cake, and threatens to smash it onto the sidewalk if Bashir doesn't hand over his wallet. There's nothing in his wallet other than a few dollars and some old business cards, and he is really looking forward to eating the cake. Bashir decides to comply and so he gives Greta his wallet.

Greta's threat to smash Bashir's cake onto the sidewalk adds a cost to refusal and so changes the choice calculus for Bashir. But Greta's threat to do wrong doesn't seem to force Bashir to hand over his wallet. Granted, by making it the case that he cannot have both his cake and his wallet, Greta's threat does force him to choose between the two. But, even if handing over his wallet is now what he has most reason to do (and let's suppose it is), that isn't the same as his choice to do so being forced. He is wrongly forced into this choice situation by Greta - he ought to be able to keep both his wallet and his cake-but, unlike Sreena, his choice within it - to hand over his wallet rather than see his cake destroyedisn't forced.

Why then is Sreena's choice to hand over her wallet in Mugging 1 forced when Bashir's in Mugging 2 is not? Simply put, her choice is forced because she loves Neelam. Sreena cannot refuse to hand over her wallet-it is not an option for her-because doing so would count as a betrayal of her love for Neelam and she cannot betray that love. Sreena is in this way subject to deliberative necessity: while Max's threat wrongly forces her into a choice situation where she must choose between her wallet and Neelam, her love for Neelam gives her no option but to choose her. Thus, it is via Sreena's love for Neelam that Max forces her choice to hand over her wallet. In a case like Mugging 1, the work the coercer does by issuing a threat is to force the coercee into a choice situation structured so that her commitments give her no option but to choose in the way the coercer wants. Thus, by using her commitments and the obligations constitutive of them in this way, he uses her agency against her and for his own ends. ${ }^{25}$

If she were to explain herself afterwards, Sreena might say something like "I didn't have a choice" or, if she's familiar with Martin Luther's famous, if apocryphal, 'Here I stand', she might (somewhat stiltedly) say "I could do no other." The incapacity here is what Bernard Williams identifies as a deliberative

${ }_{25}$ In Mugging 1, what forces her to choose to hand over her wallet is likely overdetermined: as Neelam's mother, Sreena's commitment to Neelam makes refusing to hand over her wallet unthinkable; and, as a person, her commitment to human life in general would make refusing to hand over to wallet unthinkable even if Neelam were not her daughter but rather a stranger. 
incapacity. ${ }^{26}$ Given the consequences for Neelam, the possibility of refusing to hand over her wallet is unthinkable for Sreena, and, as Gary Watson puts it, "the unthinkability of [refusal, in Sreena's case] consists in its being 'out of the question,' in its being altogether off the deliberative screen." 27 In this situation, Sreena's love not only gives her certain powerful reasons to hand over her wallet but it also silences the reasons for refusal: that she might keep her money if she were to refuse is a consideration that, in this context, her love for Neelam commits her to not taking seriously as a reason. Since Sreena cannot count refusal as anything but impossible, there is nothing from her perspective for her to deliberate about and so she cannot understand her situation as presenting her with any options but one. Thus, she cannot understand herself as having any choice about what to do. Watson continues:

[J]udgments of impossibility of this kind are often deliberative starting points rather than conclusions; they indicate the boundaries of the space of reasons in which deliberation takes place. [...] To say a proposal is impossible is to give it a certain status: it means that it is not eligible for consideration. This defines a narrower sense of option from that given by the basic concept of what a person can do-only some courses of action whose realization depend on the agent's choice are what we might call deliberative options. ${ }^{28}$

In loving Neelam, Sreena takes a stand with regard to what matters to her-her love for Neelam is thus a core part of her practical identity-and it is to this stand-taking as an agent that the necessity at issue attaches. ${ }^{29}$ And so, it is because Sreena has taken the stand she has with regard to Neelam that Max's threat doesn't merely force her into this choice situation but also forces her to hand over her wallet. While Greta's threat in Mugging 2 wrongly restricts Bashir's choice to two deliberative options - hand over his wallet or see his cake

${ }^{26}$ Williams, "Moral Incapacity," 61-2, 68. As his title indicates, Williams himself calls these incapacities 'moral incapacities'; however, it is clear throughout that Williams is using 'moral' here quite broadly, broadly enough that 'deliberative incapacity' is a better term.

27 Watson, "Volitional Necessities," in Agency and Answerability, 107. The notion of 'unthinkability' comes originally from Harry Frankfurt's "Rationality and the Unthinkable" in The Importance of What We Care About.

${ }^{28}$ Watson, "Volitional Necessities," 108. See also Williams, “Moral Incapacity," 60.

${ }^{29}$ Watson, "Volitional Necessities," 104. Relatedly, Jeffrey Blustein argues in Care and Commitment that those options are 'unthinkable' that "one cannot consider oneself doing without experiencing a grave loss of self-respect" (117). Alternatively, he says we can understand 'unthinkability' thusly: "we might say that $y$ is not entertainable as a serious option by $S$ if $S$, imaginatively trying on $y$ for size, so to speak, could not bear to be the sort of person who does $y^{\prime \prime}$ (117). 
destroyed-Max's threat wrongly restricts Neelam's choice to one-hand over her wallet - thus forcing her choice. Understanding the coercion in a case like Mugging 1, a clear case of forced choice, thus requires appealing to the thought that I aim to use in understanding the exploitation of the adjunct, namely that one person can force another to choose by taking advantage of what that other cares about and, more specifically, of the obligations that care generates for her.

\subsection{Forcing another's choice: exploitation}

Consider now a paradigm case of exploitation in a market economy. Assume about this economy that the social safety net is minimal and largely restricted to the elderly and to mothers with young children and that the dominant ideology emphasizes individual self-reliance.

Subsistence Wage: Darius, a 30-something single man, finds himself unemployed. Darius cannot rely on the state for subsistence aid; and, even if he could, he wouldn't: he'd find doing so deeply shameful (the same holds, unsurprisingly, for the prospect of relying on private charities). Rosa has advertised for a full-time employee, and Darius is one of several applicants. Though she could pay a decent wage, she offers Darius the job but for a subsistence wage. With Rosa's the only job offer he has and with no realistic prospects of a better offer elsewhere, he accepts it.

To be sure, Darius does benefit from accepting Rosa's offer: he will be able to meet his basic needs and in a way that also meets the demands of self-reliance. If this is a case of exploitation, then, it's one of mutually advantageous exploitation. Why think the terms are unfair? That Darius would prefer to earn more (as he surely would) doesn't by itself justify a claim that the terms of Rosa's offer are unfair. I suspect that what informs the judgment that the terms are unfair is a certain basic conviction about justice in a market economy, namely that market participants working full-time are entitled that the wages for their work at least be sufficient to live a decent life. I find this 'decent life' standard quite plausible, but I won't defend it here, since, in the dispute at issue, the exit options response to the adjunct's claim of exploitation doesn't deny that the university's offer is unfair; it asserts that, even if it is unfair, the fact that the adjunct has exit options - she can walk away, even if she'd prefer not to-undermines the claim, required for the charge of exploitation, that the university takes advantage of her. 
Darius' choice to accept Rosa's offer in Subsistence Wage is forced, and this forcing is made possible by his recognition of his basic needs. His basic needs are, in this context, a vulnerability of agency: they make it the case that he has no other option but to accept the offer. Most find it uncontroversial that basic needs have a particular ability to force choice, but that is because we take persons' selflove - their basic commitments to themselves and their own lives - for granted. It is to his self-love that the deliberative necessity that forces Darius' choice attaches, making refusing Rosa's offer unthinkable-it's out of the question - and so not an option for him. In this way, the judgment that Darius has no choice but to accept Rosa's offer doesn't require that Darius' acceptance be motivated by actual pangs of hunger; that it's motivated by his recognition that accepting Rosa's offer is the only way for him to secure himself, for a time, against the risk of hunger is sufficient. Cases like Subsistence Wage are cases of exploitation, then, because the exploitee is in a choice situation where he is subject to deliberative necessity: his commitments (here, Darius' self-love) force him to accept the exploiter's unfair offer; what work the exploiter does is to structure the offer-and thus the exploitee's choice situation - so that she may take advantage of his commitments and so also his agency, using them against him and for her own ends.

Notice what's at work in Subsistence Wage. Of course, there are Darius' subsistence needs. But they by themselves don't make it the case that he has no other option but to accept Rosa's offer. It is open to him, for instance, to meet these needs by living as a freegan, retrieving discarded (but still edible) food, along with other items, from store and restaurant dumpsters. It is also open to him to meet these needs by relying on charity, on food pantries, soup kitchens, shelters, and the like. If we just consider Darius' subsistence needs, then, accepting Rosa's offer does not seem to be his only option and, in fact, these other options seem preferable in that they don't require accepting an unfair offer. His subsistence needs aren't, however, the only ones at stake here; some of what might be called his identity needs are also at stake. In this case, he has not only a need for food but also a need for food fit for humans, and what makes food fit for humans is not merely that it be physically nourishing. In a relatively prosperous market economy, food that has been thrown away as garbage will, for that reason, not count as 'fit' for human consumption; as a result, it will be degrading to have to eat such food. In the same way, in a market economy where selfreliance is prized, having to rely on charity to meet one's subsistence needs will also be degrading. Thus, unless we think that Darius has a need not only to provide for his subsistence but also a need that he be able to do so in a way that 
doesn't require that he degrade himself in these ways - he owes himself that we will be unable to justify the judgment that Darius has no choice but to accept Rosa's unfair offer. In other words, if we are to judge that Rosa exploits Darius in Subsistence Wage, we must hold that she takes unfair advantage of him by taking advantage not only of his subsistence needs but also of these basic identity needs as vulnerabilities of his agency, needs which together leave him no choice but to accept her unfair offer.

I've understood Darius' unwillingness to live as a freegan or to rely on charity as arising out of an 'identity need' he has to not act in ways that, on his view, are degrading. My claim, though, is not Darius has a "real" or genuine need to avoid relying on charity or foraging for food in dumpsters; perhaps selfreliance isn't nearly as valuable as he and the society around him think, and perhaps freegans are right to find opting out of the market economy to be freeing rather than degrading. ${ }^{30}$ The language of need here is meant to make a point about the felt character of Darius' unwillingness: the necessity he feels not to betray the basic values and commitments that, as part of his practical identity, are at stake here in Subsistence Wage has the force and constancy that are characteristic of needs. ${ }^{31}$ But we needn't use the language of need here: the values that have given content to Darius' obligation to himself not to degrade himselfan obligation at the core of his sense of himself as a person-make it the case that, for him, accepting Rosa's unfair offer is his only deliberative option, for none of the other ways he might meet his subsistence needs (freeganism, charity) are thinkable for him. Even if these other ways should be thinkable for him, what matters for the question of exploitation is this fact that they are not, for, along with his recognition of his subsistence needs, this fact is a vulnerability of agency that Rosa takes advantage of in making her unfair offer.

${ }^{30}$ Here my argument departs from the view Serena Olsaretti defends in Liberty, Desert, and the Market. She argues there that something is not an option for a person when that option is "unacceptable" and an option is unacceptable "in accordance with an objective standard of wellbeing" (154). On her view, then, Darius is forced to accept Rosa's offer only if freeganism is, in fact, not an acceptable option for him. My view, on the other hand, remains agnostic with regard to this question.

${ }^{31}$ I take this point about the subjective qualities of needs from Frederick Neuhouser's discussion of the role of need in Rousseau's account of freedom and independence. See Frederick Neuhouser, "Freedom, Dependence, and the General Will," 375-76. 


\subsection{Exploiting the adjunct}

Now back to the adjunct. The adjunct's vocational commitment comes in two parts: first, a commitment to engage in the activity of teaching, and, second, a commitment to live up to the demands of that activity when in the classroom. The latter, as I've noted, is what particularly qualifies her for the job: the university needs to hire someone with that commitment if it is to ensure the integrity of the classroom. But her vocational commitment doesn't just qualify her for the job. It's also a vulnerability of her agency that makes it possible for the university to exploit her.

The case of the adjunct is a bit complicated, mainly because of how she is compensated: the adjunct is paid a lump sum in exchange for the labor-time required to teach the course; as a result, the process that determines the terms of her employment-how much work for how much pay-plays out over a series of choice situations she faces over the course of the semester. The first choice situation is the contract offer. Here, the adjunct is offered a few courses for a certain amount of money, and the amount, let's suppose, is predictably insufficient to adequately compensate the work required. But, in the normal case in which the courses are offered just before the semester begins, her alternative to accepting the university's terms is that she has no courses to teach that semester. ${ }^{32}$ Thus, if she is to continue to be able to think of herself under the description of 'college teacher,' however tenuous doing so might be as an adjunct, she must accept the offer. Given her vocational commitment, and its role in giving her practical life meaning and value, refusing the offer is not something she can seriously entertain as an option.

But, someone might object, even if she has no option but to accept the offer, the adjunct does retain post-acceptance much of the ability to decide how much time she devotes to teaching the course and thus also what her pay rate will be. We don't yet have a case of exploitation here, the objector continues, for whether the transaction is unfair is something that's actually up to her over the course of the semester. To see why this is mistaken, we need to consider the second (recurring) choice situation the adjunct faces over the course of the semester, the one determining how much work she actually does. The adjunct is now the course instructor and so her professional norms kick in, governing how she teaches the course and thus how much work she does. And, given her vocational commitment, the alternative to doing whatever is required to teach the course

\footnotetext{
${ }^{32} \mathrm{Or}$, at best, that she is offered a similar contract at a nearby school.
} 
well to her particular students - that is, doing less than that because of considerations of pay - is not something she can seriously entertain as an option, for doing so would require that she violate what are, for her, serious obligations. This is what is going on in my conversation with Sara: because of who she is (and who the university hired her to be), she is unable to regulate the amount of work she does in teaching the course with the aim that she end up having been paid fairly.

The vocationally committed adjunct is thus vulnerable to exploitation by her university. And this is the case even while it is true of her that, if she looked for a decently paying job outside of academia, she would find one. The exit options response fails. ${ }^{33}$

\section{CARE PROFESSIONS, EXPLOITATION, AND MORAL IDENTITY}

The situation of the adjunct is not unique. In a market economy, professionals in general-or at least those with vocations - are vulnerable in this way to exploitation, a vulnerability that arises out of central features both of professions and of a market economy. But, that said, certain professions-the care professions - are characterized by vocations that are moralized. In these professions, one aims for certain morally significant goods of other people and so, when a person is professionalized into a care profession, she comes to regard aiming for these goods of others as part of a life worth living, as something she ought to do. One result is that this professionalization gives content to the person's moral identity: a morally committed person is, in part, concerned to do good to/for others but one has some latitude to decide what goods and which others; being professionalized into a care profession is one way to make these decisions and thus give content to one's moral identity. As I argue in this section, exploitation of a person's vocational commitment is more objectionable when that vocation is moralized because the exploitation at issue will not be merely exploitation by way of the person's vocational commitment but also by way of her more basic moral commitments, ones that have been given content by her

\footnotetext{
${ }^{33}$ It's important to note that this argument is compatible with the claim that this adjunct is not entitled to a job teaching college courses. That she has come to regard teaching as something she ought to do with her life-indeed, as a need she has-doesn't by itself generate a claim on the university that she be given the opportunity to teach. The argument also doesn't challenge the claim that the university may take advantage of her vocational commitment as something that qualifies her to teach by hiring her as an adjunct. What it may not do is take advantage of her vocational commitment as a vulnerability of her agency.
} 
vocation. My argument here focuses on nurses, but it applies to care workers in general: social workers; teachers of disadvantaged students in underfunded schools; public-interest lawyers, particularly those working in domestic violence, immigration, and child and family law; public defenders; and so on. ${ }^{34}$

\subsection{Exploiting the nurse's commitment to morality}

Consider the case of a nurse working in a busy Emergency Department in a non-unionized public hospital in a major American city. There are reliably more patients in need of care than scheduled staff to care for them, and so she regularly stays after her shift is over-she works for free-to care for patients. What makes this sort of chronic understaffing that nevertheless doesn't appreciably harm patient care possible for the hospital is the exploitation of its nurses via their vocational commitments to get them to do some work for free.

Imagine such a nurse. She is committed to nursing as her vocation, but it is also her job. Her shift is over, and so she prepares to leave. But in the hallway she sees a patient on a gurney in pain and in need of care; this patient hasn't yet been attended to by anyone, and the staff just beginning their shifts won't attend to him for some time. This nurse faces a decision. She may:

(a) leave the hospital, and so leave that patient in need, because her shift is over; or,

(b) stay and see to it that this patient gets the care he needs, even though her shift is over.

For this nurse to respond to such a situation with "I'm not going to help this patient, since I'm now off the clock" would be for her to betray her vocation, since she would be allowing market norms - work is done for pay - to intrude where they should not. Thus, when considering the first option, she faces the question: "But what kind of nurse would I be?" Given her vocation, leaving the patient in need is not an option for her.

\footnotetext{
${ }^{34}$ I don't intend my shift from adjunct teaching to nursing to imply that college teaching doesn't belong in the category of morally significant care-work. I switch to nursing in this section only because it much more obviously belongs to the category of care-work. For an account of college teaching as a vocation that makes clear the extent to which it is a kind of care-work, see Lawrence Blum's "Vocation, Friendship, and Community: Limitations of the Personal-Impersonal Framework" in Moral Perception and Particularity.
} 
But what's notable here is that, when this nurse considers leaving, she seems also to confront a different and deeper question: "But what kind of person would I be?" Leaving this patient in need is not an option for her, but not simply because of her vocational commitment to nursing; it's not an option also because of her commitment to morality: leaving this patient in pain and in need of care when she could help is, for her, morally unthinkable. And so, in deciding to understaff the Emergency Department so as to lower labor costs, the hospital exploits its nurses not merely by way of their vocational commitments but also by way of their commitments to morality.

As Peta Bowden notes in her illuminating account of nursing, "nursing care is constituted in the relationship of response to determinate pleas for help" and these responses are responses to "recognized breakdown[s] in the functioning of personal, embodied well-being." 35 The aim of nursing is to realize certain basic goods for patients - health, survival, the preservation or reclamation of dignity and/or agency, or, at a minimum, comfort and lack of pain - by following a set of professional norms. Hospitals, particularly Emergency Departments, do a crucial part of the work of care, the morally necessary concern for the vulnerable and needy among us (here, care for the sick and the dying). The professional norms governing the nurse are those that, if followed, enable the nurse to do her part of the morally necessary care-work of the Emergency Department. ${ }^{36}$

The nurse's "clinical know-how," as Bowden explains, includes "the ability to make finely graded distinctions in patients' conditions, to interpret the importance of subtle changes before measurable alterations occur, to recognize problems that ought to be solved." 37 In this way, nursing requires a special sort of sensitivity in one's perceptions of other people and their needs. As Bowden puts it: "nursing care is a particular way of entering the world of another person [and his] specific experiences of affliction." 38 The patient is vulnerable and in need - he may be sick or dying, in pain, in distress, struggling with feelings of loss, anger, or shame-and the nurse must be attentive to those needs and

\footnotetext{
${ }^{35}$ Bowden, Caring, 101, 103.

${ }^{36}$ As Bowden explains about the social context of nursing practice, " $[\mathrm{m}]$ ost frequently the parties [nurse and patient] are strangers to each other, not personally involved in each other's lives through ties of blood or friendship. As a consequence, the caring practices of nursing are subject directly to the determinations of publicly administered norms and structured by the demands of publicly sanctioned conduct" (ibid., 101).

37 Ibid., 106.

${ }^{38}$ Ibid., 106-07.
} 
struggles. ${ }^{39}$ Her training into the profession thus involves developing the ability to see these needs when they are present, to pick them out as salient.

This sort of sensitivity that nursing requires is arguably also an enriching of the nurse's moral perception: she develops a greater sensitivity to what requires moral attention, a sensitivity that makes particular sense in her case because she has also developed the skills and has the supplies at hand to respond with care to persons with those needs. This sort of sensitivity can be understood as the ability, developed by the person's professionalization into nursing, to apply nursing-specific versions of what Barbara Herman has called "rules of moral salience": "Acquired as elements in a moral education [and, here, in a nursing education], they structure an agent's perception of [her] situation so that what [she] perceives is a world with moral features." 40 And once perceived, these moral features qua moral demand inclusion in her practical deliberations. What is distinctive, then, about nursing as a profession, as well as other professions that do the work of care, is that the process of professionalization-of educating persons into the profession and so of cultivating in them that identity-includes this sort of moral education, this further and focused development of one's moral sensitivity and perception. The nurse internalizes more sophisticated rules of moral salience when she is trained as a nurse to be attentive to the needs her patients arrive with and to their "specific experiences of affliction" - the world she sees, or at least this part of her world, has more moral features than the corresponding part of the world we who aren't nurses see-and so the careobligations that a patient's needs and afflictions place on her are felt not only as obligations she has as a nurse but also as moral obligations she has as a person, one who happens to be trained as a nurse.

\subsection{Why this exploitation is particularly objectionable}

Why think that the exploitation of the nurse, and of care workers in general, is particularly morally troubling? There are two reasons. First, since a person's

\footnotetext{
${ }^{39}$ As Bowden notes, the vulnerabilities of the patient are not restricted to physical breakdowns: "Illness presents us with explicit and indisputable evidence of the pervasiveness of chance and vulnerability as inherent structures of our lives. As the sufferers of assaults of happenstance, we experience the inescapable 'objectness' of our bodies - or in more complicated ways, our minds: the defenceless, thing-like fragility of body or mind is experienced in opposition to our purposes and values. Nursing care is a response to the specific experiences of affliction, that carries the meaning of this essential dimension of our humanity" (ibid., 112-13).

${ }^{40}$ Barbara Herman, "The Practice of Moral Judgment" in The Practice of Moral Judgment, 77.
} 
commitment to morality will normally be one of the deepest commitments she has, living up to it can demand greater sacrifice than living up, say, to a nonmoralized vocational commitment; thus, taking advantage of her by way of this commitment would give one more power over the transaction, for there will be a wider range of terms - and greater unfairness - that she will regard herself as having no other option but to accept. Suppose our nurse has other important projects and relationships structuring her non-work life: she has a partner, or children; she is a political activist; or, she is pursuing a further degree at night. She surely understands that, by staying on after her shift, she is giving up valuable opportunities to pursue these other projects and relationships. And yet she regularly decides to stay on after her shift. Here, because the hospital is not only using her vocational commitment against her but also her commitment to morality, she is unable to assert the importance of these other projects and commitments by leaving when her shift is up. In exploiting her, the hospital thus attaches a new cost to her commitment to morality: when she decides to stay after her shift is done, she sacrifices some of her ability to live up to the demands of her other valuable projects and relationships, but, because she has no option but to stay-leaving is, from her perspective, morally unthinkable-she is forced to make that sacrifice.

And, second, the nature of the nurse's vulnerability of agency-what the hospital exploits - is importantly different than that of a professional whose vocational commitment does not directly involve more basic moral commitments (an artist, for instance). This other professional is vulnerable to exploitation only so long as she has the vocation, for it is only then that she must think of herself under the relevant description. And it is open to her to take steps over time to give up that vocation and so that description under which she values herself, thus making alternatives other than this profession thinkable as options for her. In other words, it is open to her to rid herself of this vulnerability to exploitation. For the nurse, however, the nature of her vocational commitment makes it more difficult for her to rid herself of this vulnerability to exploitation. Her vocation, nursing, is one of the main ways that she has filled out and made concrete the description she has of herself as a morally committed person. In this way, if she is to give up her vocation and so the description of herself as a nurse, she must also modify the way she has filled out for herself what it means to be a morally committed person, and this modification must still allow her to respond appropriately to the world that has the moral features that she, because of her nursing training, will still tend to perceive it as having. This is a much more radical revision of her practical identity than giving up one's vocation is for a 
professional not engaged in care-work, and giving that up is, for that professional, already a major revision.

\section{CONCLUSION}

In a market economy, members of professions - or at least those for whom their profession is a vocation - are vulnerable to a distinctive kind of objectionable exploitation, namely the exploitation of their vocational commitment. And that they are vulnerable in this way arises out of central features both of professions and of a market economy. Furthermore, for certain professions - the care professions - this sort of exploitation is especially objectionable, since, for these professions, the exploitation at issue is not only exploitation of the professional's vocational commitment but also of her even more basic commitment to morality. When an institution exploits not only a professional's vocational commitment but also her commitment to morality, this exploitation sets the professional's ability to live up to the demands of her own valuable projects and relationships against her ability to live up to the demands of her commitment to morality, thus forcing her to sacrifice the former for the sake of the latter.

\section{ACKNOWLEDGMENTS}

I am grateful to Richard W. Miller, Jyl Gentzler, Timothy Hinton, Nathaniel Jezzi, Shelly Duford, Derek Walker, and two anonymous reviewers for their questions and criticisms. I also thank audiences at the Wharton School's Normative Business Ethics Workshop, Amherst College, and the Pacific APA, to whom I presented earlier versions of the argument contained in this paper.

\section{REFERENCES}

Akerloff, George A. and Rachel E. Kranton. "Economics and Identity." The Quarterly Journal of Economics 65 (2000): 715-53.

Anderson, Elizabeth. Value in Ethics and Economics. Cambridge, MA: Harvard University Press, 1993.

Benabou, Roland and Jean Tirole. "Intrinsic and Extrinsic Motivation." Review of Economic Studies 70 (2003): 489-520. 
Besley, Timothy and Maitreesh Ghatak. "Competition and Incentives with Motivated Agents." The American Economic Review 95 (2005): 616-36.

Blum, Lawrence A. Moral Perception and Particularity. Cambridge UK: Cambridge University Press, 1994.

Blustein, Jeffrey. Care and Commitment: Taking the Personal Point of View. Oxford UK: Oxford University Press, 1991.

Bowden, Peta. Caring: Gender Sensitive Ethics. New York: Routledge, 1997.

Brennan, Jason and Phillip Magness. “Are Adjunct Faculty Exploited: Some Grounds for Skepticism." Journal of Business Ethics, published online Sept 2016, https://doi.org/10.1007/s10551-016-3322-4.

Farzin, Y.H. "The Effect of Non-Pecuniary Motivations on Labor Supply." The Quarterly Review of Economics and Finance 49 (2009): 1236-59.

Finley, Laura. "How Adjuncts Are Exploited" Consortiumnews.com, July 25, 2015, consortiumnews.com/2015/07/25/how-adjunct-professors-are-exploited (accessed June 19, 2017).

Folbre, Nancy and Julie A. Nelson. "For Love or Money-Or Both?" Journal of Economic Perspectives. 14 (2000): 123-40.

Frankfurt, Harry. The Importance of What We Care About. Cambridge UK: Cambridge University Press, 1988.

Frey, Bruno. Not Just for the Money: An Economic Theory of Personal Motivation. Cheltenham, UK: Edward Elgar, 1997.

Frey, Bruno and Reto Jegen. "Motivation Crowding Theory" Journal of Economic Surveys 15 (2001): 589-611.

Herman, Barbara. The Practice of Moral Judgment. Cambridge, MA: Harvard University Press, 1993.

Heyes, Anthony. "The Economics of Vocation or 'Why is a Badly Paid Nurse a Good Nurse?'" Journal of Health Economics 24 (2005): 561-9.

Kittay, Eva Feder. Love's Labor: Essays on Women, Equality and Dependency. New York: Routledge, 1999.

Korsgaard, Christine. The Sources of Normativity. Cambridge UK: Cambridge University Press, 1996.

Luban, David. Legal Ethics and Human Dignity. Cambridge UK: Cambridge University Press, 2007.

Nelson, Julie A. "Of Markets and Martyrs: Is It OK to Pay Well for Care?" Feminist Economics 5 (1999): 43-59. 
Nelson, Julie A. and Nancy Folbre, "Why a Well-Paid Nurse Is a Better Nurse," Nursing Economics 24 (2006): 127-30.

Neuhouser, Frederick. "Freedom, Dependence, and the General Will" The Philosophical Review 102 (1993): 363-395.

Olsaretti, Serena. Liberty, Desert, and the Market: A Philosophical Study. Cambridge UK: Cambridge University Press, 2004.

Prendergrast, Candace. "Intrinsic Motivation and Incentives" American Economic Review: Papers E Proceedings 98 (2008): 201-205.

Raz, Joseph. “Liberating Duties.” Law and Philosophy. 8 (1989): 3-21.

Roberts, Jennifer and Michael Dietrich. "Conceptualizing Professionalism: Why Economics Needs Sociology." American Journal of Economics and Sociology 58 (1999): 977-998.

Sample, Ruth. Exploitation: What It Is and Why It's Wrong. Lanham, MD: Rowman \& Littlefield, 2003.

Titmuss, Richard. The Gift Relationship: From Human Blood to Social Policy. New York: Vintage Books, 1972.

Watson, Gary. Agency and Answerability: Selected Essays. Oxford UK: Oxford University Press, 2004.

Wertheimer, Alan. Exploitation. Princeton, NJ: Princeton University Press, 1996.

Williams, Bernard. "Moral Incapacity." Proceedings of the Aristotelian Society 93 (1993): 59-70.

Wood, Allen W. "Exploitation." Social Philosophy and Policy 12 (1995): 136-58.

Wood, Allen W. Karl Marx. New York: Routledge, 2004. 